\title{
FAKTOR RESIKO INFEKSI SALURAN KEMIH PADA PASIEN DENGAN BATU SALURAN KEMIH
}

\section{RISK FACTOR OF URINARY TRACT INFECTION IN PATIENTS WITH URYNARY STONE DISEASE}

\author{
Alharsya Franklyn Ruckle ${ }^{1}$, Akhada Maulana ${ }^{2}$, Tanaya Ghinowara ${ }^{1}$ \\ ${ }^{1}$ Program Studi Urologi Fakultas Kedokteran Kesehatan Masyarakat dan Keperawatan Universitas \\ Gadjah Mada/RSUP Dr. Sardjito Yogyakarta \\ ${ }^{2}$ SMF Urologi RSUD Provinsi Nusa Tenggara Barat \\ Korespondensi: dr. Alharsya Fransklyn Ruckle. Email: ruckle.alharsya@gmail.com
}

\begin{abstract}
ABSTRAK
Infeksi saluran kemih (ISK) dan batu saluran kemih (BSK) saling terkait. Pada sekitar 10-15\% pasien ISK terbentuk BSK. Infeksi yang disebabkan bakteri yang memproduksi urease akan membentuk batu infeksi. Sebaliknya ISK juga sering ditemukan pada pasien dengan BSK. Komplikasi dari BSK antara lain bakteriuri asimptomatik, ISK, dan sepsis. Beberapa faktor resiko dilaporkan dapat menimbulkan ISK pada BSK. Penelitian ini bertujuan mengetahui faktor-faktor risiko yang berpengaruh terhadap kejadian ISK pada pasien BSK. Penelitian ini merupakan penelitian observasional analitik prospektif, menggunakan metode potong lintang, dengan 20 sampel penelitian. Hasil penelitian ini adalah jumlah batu berisiko secara signifikan terhadap kejadian ISK, sedangkan faktor risiko usia, jenis kelamin, letak batu, dan adanya obstruksi tidak berpengaruh secara sigifikan terhadap munculnya ISK pada pasien BSK. Secara keseluruhan, frekuensi kejadian ISK pada pasien BSK sebesar 45\%. Kesimpulan penelitian ini adalah jumlah batu merupakan faktor risiko ISK pada pasien BSK.
\end{abstract}

Kata Kunci: Infeksi Saluran Kemih, Batu Saluran Kemih, Faktor Resiko, Jumlah Batu

\section{ABSTRACT}

Urinary tract infections (UTI) and urinary stones disease are interrelated. In about 10-15\% of UTI patients have developed to BSK. In Urinary track Infections, bacteria will produce urease that form infection stones. But UTI is also often found in patients with urinary stone. Several risk factors in urinary tract stones cause UTI, have been reported. This study aimed to determine the risk factors that influence the incidence of UTI in urinary stone disease patients. This study $w$ a prospective analytic observational study, using a crosssectional method, with 20 samples. The results of this study were the number of stones had a significant risk of UTI, while the risk factors for age, gender, location of stones, and the presence of obstruction had no significant effect on the appearance of UTI in urinary stone disease patients. Overall, the incidence of UTI in urinary stone disease patients was $45 \%$. We concluded that the number of stones was a risk factor for UTI in urinary stone disease patients.

Keyword: Urinary Track Infection, Urinary Stone Disease, Risk Factor, Number Of Stone

How To Cite: Ruckle, A., Maulana, A., \& Ghinowara, T. (2020). FAKTOR RESIKO INFEKSI SALURAN KEMIH PADA PASIEN DENGAN BATU SALURAN KEMIH. Biomedika, 12(2), 124.-130 doi:https://doi.org/10.23917/biomedika.v12i2.10812

DOI: https://doi.org/10.23917/ biomedika.v12i2.10812 


\section{PENDAHULUAN}

Batu saluran kemih (BSK) merupakan penyakit yang banyak ditemukan di dunia, dengan insidensi mencapai $1-5 \%$ di Asia, 5$10 \%$ di Eropa, dan $13-15 \%$ di Amerika serikat (Costa et al., 2007). Beberapa laporan juga menyatakan bahwa insidensi dan prevalensi BSK di banyak negara di dunia meningkat. Peningkatan prevalensi global BSK berhubungan dengan membaiknya sistem pemeliharaan kesehatan negara industri dan menurunnya kesenjangan sosial dalam masyarakat dunia (Romero et al., 2010).

Penyakit BSK masih menempati porsi terbesar dari jumlah pasien urologi di Indonesia. Selama kurun waktu 1997-2002 terdapat 2439 penderita batu ginjal di Rumah Sakit Umum Pusat Cipto mangunkusumo (RSCM) dengan jumlah tindakan yang dilakukan sebanyak 3165 tindakan. Prevalensi penyakit antara laki-laki dan perempuan diperkirakan 3 berbanding 1, dengan puncak usia dekade keempat dan kelima (Rahardjo dan Hamid, 2004).

Infeksi saluran kemih (ISK) dan batu saluran kemih (BSK) saling terkait. Batu adalah konsekuensi dari ISK pada sekitar 10-15\% pasien dengan penyakit batu (Thomas and Tolley, 2008). Sementara sekitar $10 \%$ dari rawat

inap karena batu diperumit oleh infeksi yang memerlukan drainase (Yoshimura, 2005). Terjadinya infeksi pada pasien dengan batu yang sudah ada sebelumnya, terutama jika terdapat obstruksi, adalah salah satu kondisi paling serius dalam praktik urologis (Thomas and Tolley, 2008).

Infeksi saluran kemih (ISK) sering ditemukan pada pasien dengan BSK. Infeksi persisten yang disebabkan bakteri yang memproduksi urease akan membentuk batu infeksi yang terdiri dari monoammonium urate, struvite (magnesium ammonium phosphate), dan atau carbonate apatite. Hal tersebut membuat terapi BSK lebih rumit. Komplikasi dari BSK seperti bakteriuria asimptomatik, ISK, dan sepsis telah diketahui pada kasus pengobatan dengan Extracorporeal Shock-Wave Lithotripsy (ESWL). Pasien dengan batu multipel mungkin mengalami sindrom respons inflamasi sistemik pasca operasi setelah nefrolitotomi perkutan (PCNL), beberapa persen berkembang menjadi urosepsis, yang dapat menyebabkan syok septik. Dari semua infeksi saluran urogenital, pielonefritis adalah yang paling parah dan menyebabkan komplikasi berbahaya (Wolf, 2012). 
Beberapa penelitian tentang faktor risiko infeksi pada pasien dengan BSK telah dipublikasikan Schwartz dan Wong meneliti penggunaan kateter, obstruksi saluran kemih, gangguan neurogenik kandung kemih, asidosis tubulus ginjal distal menjadi faktor risiko ISK dan dapat berkembang menjadi batu karena infeksi. Li et al. (2013) menemukan bahwa pada pasien dengan BSK, jenis kelamin perempuan dan diabetes mellitus merupakan faktor resiko kerentanan terjadinya syok septik setelah perawatan PCNL. Selain faktor-faktor ini, mungkin ada beberapa yang terkait dengan pembentukan batu. Misalnya, merokok dan konsumsi alkohol (Yongzhi et al., 2018).

Variasi tempat tinggal secara umum mempengaruhi pengaruh kebiasaan hidup, diet dan standar perawatan medis pada pembentukan batu urin (Knoll et al., 2011). Hal tersebut mendorong peneliti untuk melakukan penelitian di Indonesia untuk menilai faktor resiko ISK pada pasien dengan BSK. Tujuan dari penelitian ini adalah mengetahui gambaran deskriptif pasien ISK yang menderita BSK dan mengetahui apakah jenis kelamin, usia, jumlah batu, dan obstruksi yang terjadi pada pasien dengan batu saluran kemih beresiko menimbulkan infeksi.

\section{METODE}

Penelitian Ini adalah penelitian observasional analitik prospektif tentang faktor resiko infeksi saluran kemih pada pasien dengan batu saluran kemih. Analisis faktor resiko menggunakan metode cross sectional. Penelitian sudah disetujui oleh komisi etik Fakultas Kedokteran Universitas Muhammadiyah Surakarta nomor 2945/B.1/KEPKFKUMS/IV/2020. Subjek penelitian adalah pasien urologi di RS X Mataram dengan kriteria inklusi yaitu pasien terdiagnosis batu saluran kemih dan data pasien lengkap. Kriteria eksklusi adalah penggunaan antibiotic 3 hari sebelum pemeriksaan, dan gangguan ginjal. ISK didefinisikan sebagai salah satu tanda atau gejala berikut yaitu demam $>37,8^{\circ} \mathrm{C}$ dengan disuria, sering buang air kecil, buang air kecil yang mendesak, dan / atau nyeri suprapubik dengan pertumbuhan bakteri $>105 \mathrm{CFU} / \mathrm{mL}$ dari urin midstream. Sedangkan BSK didefinisikan sebagai terbentuknya endapan batu pada saluran kemih yang dibuktikan dengan pemeriksaan radiografi. Data didapat dari data sekunder rekam medis. Data profil ini mencakup usia, jenis kelamin, jumlah batu, dan ada atau tidaknya osbtruksi. Jumlah sampel diambil dri seluruh populasi pasien batu saluran 
kemih yang mengalami infeksi pada bulan Juli 2019 di RS X Mataram. Data ini kemudian ditabulasi dan ditampilkan dalam bentuk tabel dan grafik serta dianalisa menggunakan software. Data disajikan dalam bentuk deskriptif. Faktor resiko dianalisa menggunakan chi square atau fisher exact test. Analisis multivariat menggunakan teknik analisis regresi logistik untuk mengetahui semua hubungan variabel dan menentukan variabel bebas mana yang paling berpengaruh dengan variabel terikat

\section{HASIL DAN PEMBAHASAN}

Sebanyak 20 pasien rawat inap dengan BSK di RS X Mataram yang memenuhi kriteria restriksi dimasukkan menjadi subjek penelitian, terdiri dari 13 pasien laki-laki dan 7 pasien perempuan. Responden paling banyak berusia antara 40 - 60 tahun sebanyak 50\%. Letak batu berdasarkan pemeriksaan radiologis paling banyak terletak di ginjal sebanyak $65 \%$, diikuti ureter sebanyak $30 \%$, dan vesika urinaria. Obstruksi dialami oleh 11 responden (tabel 1).

Tabel 1. Analisis Statistic Hasil Penelitian

\begin{tabular}{|c|c|c|c|c|c|c|c|}
\hline \multirow[t]{2}{*}{ Faktor resiko } & \multicolumn{2}{|c|}{ Jumlah subjek } & \multicolumn{2}{|c|}{ ISK (+) } & \multicolumn{2}{|c|}{ ISK (-) } & \multirow[t]{2}{*}{$p$} \\
\hline & $\mathbf{n}$ & $\%$ & $\mathbf{n}$ & $\%$ & $\mathbf{n}$ & $\%$ & \\
\hline Jenis Kelamin & & & & & & & 0.64 \\
\hline Laki-laki & 13 & 65 & 5 & 55.6 & 8 & 72.7 & \\
\hline Perempuan & 7 & 35 & 4 & 44.4 & 3 & 27.3 & \\
\hline Usia & & & & & & & 0.9 \\
\hline$<40$ tahun & 2 & 10 & 1 & 11.1 & 1 & 9.1 & \\
\hline 40-60 tahun & 10 & 50 & 4 & 44.4 & 6 & 54.5 & \\
\hline$>60$ tahun & 8 & 40 & 4 & 44.4 & 4 & 36.4 & \\
\hline Jumlah Batu & & & & & & & 0.02 \\
\hline single & 14 & 70 & 3 & 33.3 & 11 & 100.0 & \\
\hline multiple & 6 & 30 & 6 & 66.7 & 0 & - & \\
\hline Adanya Obstruksi & & & & & & & 0.092 \\
\hline Tidak Obstruksi & 9 & 45 & 2 & 22.2 & 7 & 63.6 & \\
\hline Obstruksi & 11 & 55 & 7 & 77.8 & 4 & 36.4 & \\
\hline
\end{tabular}

Tabel 1 menunjukkan bahwa pasien lakilaki lebih banyak menderita ISK dibandingkan perempuan yaitu sebesar $55,6 \%$, dan pasien berusia $>40$ tahun lebih rentan menderita ISK. Pasien dengan obstruksi lebih rentan menderita
ISK dibandingkan tanpa obstruksi yaitu sebesar 77,8\%. Pasien dengan batu multiple memiliki tingkat infeksi lebih tinggi dibandingkan pasien dengan batu singel. Dan pasien dengan batu ginjal lebh banyak 
menderita infeksi saluran kemih dibandingkan batu ureter dan vesika urinaria.

Hasil uji analisis statistik dengan chi square maupun fisher exact test menunjukkan jumlah batu secara signifikan merupakan faktor resiko terjadinya infeksi saluran kemih dengan nilai $\mathrm{p}=0,02(<0,05)$. Sedangkan faktor resiko usia, jenis kelamin, letak batu, dan adanya obstruksi tidak berpengaruh secara sigifikan terhadap munculnya infeksi saluran kemih pada pasien dengan batu saluran kemih.

Pada penelitian ini, penderita ISK pada pasien dengan BSK lebih banyak diderita lakilaki dibandingkan perempuan, dengan angka yang tidak jauh berbeda. Hal ini dimungkinkan karena sebagian besar subjek penelitian adalah laki-laki yaitu sebesar $65 \%$. Akan tetapi dari seluruh subjek penelitian berjenis kelamin perempuan, lebih banyak responden yang menderita ISK. Pada penelitian Li dan Liu disebutkan bahwa perempuan dengan BSK lebih rentan terhadap syok septik setelah pengobatan PCNL (Li $\mathrm{K}$ 2013). Hal ini kemungkinan disebabkan karena perempuan memiliki uretra yang lebih pendek, yang membuat lebih rentan terhadap infeksi. Hampir $10 \%$ wanita mengalami ISK dalam waktu 1 tahun pengobatan PCNL, termasuk sistitis dan pielonefritis, dan sebanyak $26 \%$ ISK berulang dalam 6 bulan. (Nicolle 2008)

Pada penelitian ini usia bukan merupakan faktor resiko terjadinya ISK pada batu saluran kemih, dengan nilai $\mathrm{p}$ 0,9. Thomas and Tolley menyebutkan kebanyakan batu terbentuk pada usia yang lebih tua. (Knoll et al., 2011) Akan tetapi setiap jenis BSK memiliki insidensi yang berbeda menurut usia. Batu infeksi paling umum pada usia 60 hingga 69 tahun dibandingkan dengan kelompok usia lainnya, Daudon et al. (2004) melaporkan bahwa struvite sangat rendah pada usia 40 hingga 49 tahun, tetapi puncak frekuensi batu amonium urat diamati pada usia 0 hingga 9 tahun. Selain itu batu sistin lebih umum pada usia yang lebih muda. Angka tertinggi tercatat pada perempuan pada usia 20 hingga 29 tahun dan pada pria pada usia 30 hingga 39 tahun. Untuk menentukan pengaruh usia terhadap ISK pada BSK, responden harus dikelompokkan sesuai jenis batu sehingga seragam. Penelitian ini tidak menganalisis jenis batu, sehingga hasil penelitian menjadi tidak signifikan. Selain itu, biasanya ISK dengan bakteri penghasil urease meningkatkan kristalisasi dan pembentukan batu staghorn yang meliputi pelvis dan calix ginjal. Dilaporkan bahwa pada 59-68\% kasus, 
sebagian besar konstituen infeksius adalah batu staghorn, yang menunjukkan bahwa pasien dengan batu staghorn lebih mudah menderita ISK. (Preminger et al., 2005)

Obstruksi pada penelitian ini secara statistik tidak signifikan sebagai faktor resiko ISK pada pasien dengan BSK. Hal ini kemungkinan disebabkan sebagian besar responden menderita batu ginjal, sehingga resiko peradangan ataupun cedera di ureter minimal. Menurut Yongzi (2018) penyempitan ureter yang meradang atau cedera yang disebabkan oleh batu ketika bergerak ke ureter distal dapat dengan mudah menyebabkan infeksi.

Pada penelitian ini, Jumlah batu merupakan satu-satunya faktor resiko dengan hasil analisis statistik signifikan menyebabkan ISK pada pasien dengan BSK dengan nilai $\mathrm{p}=$ 0,02. Pasien dengan batu multipel lebih mungkin terinfeksi dibandingkan dengan batu tunggal. Hal ini bisa jadi disebabkan karena batu multipel lebih memiliki banyak kesempatan menyebabkan obstruksi/sumbatan, yang dapat dengan mudah menyebabkan retensi urin setelah itu kemungkinan ISK meningkat secara signifikan. (Yongzhi et al., 2018)
Penelitian ini memiliki beberapa kekurangan antara lain adalah jenis kuman, karena kultur kuman tidak selalu dikerjakan pada pasien. Penelitian ini juga tidak memiliki data tentang komposisi batu, yang dapat berguna untuk analisis batu infeksi. Dengan demikian, pola kuman, hubungan antara komposisi batu dan kolonisasi bakteri mungkin menjadi subjek penelitian berikutnya.

\section{SIMPULAN DAN SARAN}

Pada penelitian ini, jumlah batu berhubungan dengan kejadian ISK pada pasien dengan BSK, sedangkan usia, jenis kelamin, dan adanya obstruksi tidak berhubungan dengan kejadian ISK. Perlu dilakukan penelitian lebih lanjut dengan tambahan data berupa pola kuman dan jenis batu sehingga, hubungan antara komposisi batu dan kolonisasi bakteri dapat dianalisis pada penelitian berikutnya.

\section{DAFTAR PUSTAKA}

Costa, B., Ramis, M., and Montesinos, V. 2007. Type of Renal Calculi : Variation with Age and Sex. World $J$ Urol. Pp: 415 - 21.

Daudon, M., Dore, J-C., and Jungers, P. 2004. Changes in stone composition according to age and gender of patients: a multivariate 
epidemiological approach. Urol Res. Pp: 241-7.

Knoll, T., Schubert, A.B., Fahlenkamp, D., Leusmann, D.B., Wendt-Nordahl, G., and Schubert, G. 2011. Urolithiasis through the ages: data on more than 200,000 urinary stone analyses. $J$ Urol. Pp: 1304-11.

Li, K., Liu, C., Zhang, X., Liu, Y., and Wang, P. 2013. Risk factors for septic shock after minipercutaneous nephrolithotripsy with holmium laser. Urology. Pp: 1173-6.

Nicolle, L.E. 2008. Uncomplicated urinary tract infection in adults including uncomplicated pyelonephritis. Urol Clin North Am. Pp: 1-12.

Preminger, G.M., Assimos, D.G., and Lingeman, J.E. 2005. Chapter 1: AUA guideline on management of staghorn calculi: diagnosis and treatment recommendations. J Urol. Pp: 19912000 .

Rahardjo, D. dan Hamid, R. 2004.

Perkembangan Penatalaksanaan Batu Ginjal di RSCM tahun 1997-2001. J I Bedah Indones. Pp: 58-63.
Romero, V., Akpinar, H., and Assimos, D.G. 2010. Kidney Stone: A Global Picture of Prevalence, Incidence, and Associated Risk Factor. Review in Urology. Pp: 86 - 96.

Thomas, B. and Tolley, D. 2008. Concurrent urinary tract infection and stone disease: pathogenesis, diagnosis and management. Nature Clinical Practice Urology. Pp: 668-675.

Wolf., JS. 2012. Percutaneous Approach to the Upper Collecting System." In Campbell Walsh Urology $10^{\text {th }}$ ed. Philadelphia: WB Saunders co. Pp:1324-56.

Yongzhi, L., Shi, Y., Jia, L., Yili, L., and Xue, G. 2018. Risk factors for urinary tract infection in patients with urolithiasisprimary report of a single center cohort. BMC Urology. Pp: 1-6.

Yoshimura, K. 2005. Emergency drainage for urosepsis associated with upper urinary tract calculi. J Urol. Pp: 45862. 